Global Conferences Series:

Social Sciences, Education and Humanities (GCSSSEH), Volume 3, 2019

The $1^{\text {st }}$ International Conference on Education, Social Sciences and Humanities

DOI: https://doi.org/10.326/hum0200

\title{
The Effect of Training and Work Motivation on Employee Performance
}

\author{
Gede Putu Agus Jana Susila1, I Nengah Suarmanayasa², Putu Gede Parma ${ }^{3}$ \\ 1,2,3 Universitas Pendidikan Ganesha, Singaraja, Bali, Indonesia \\ Agus.jana@undiksha.ac.id
}

\begin{abstract}
The purpose of this study was to obtain proven explanation about the effect of: (1) Training and work motivation on employee performance at Regional Drinking Water Company (PDAM) of Buleleng Regency Branch Seririt, (2) Training on employee work motivation at PDAM of Buleleng Regency Branch Seririt, (3) Training on employee performance PDAM of Buleleng Regency Branch Seririt, and (4) Work motivation on employee performance at PDAM of Buleleng Regency Branch Seririt. This study used a quantitative causal research design. The subjects of the study were employees PDAM of Buleleng Regency Branch Seririt, while the objects were training, work motivation and performance. The data were analyzed by using path analysis. The results of the study were: (1) Training and work motivation had a positive effect on employee performance at PDAM of Buleleng Regency Branch Seririt, (2) Training had a positive effect on work motivation at PDAM of Buleleng Regency Branch Seririt, (3) Training had a positive effect on employee performance at PDAM of Buleleng Regency Branch Seririt (4) Work motivation had a positive effect on employee performance at PDAM of Buleleng Regency Branch Seririt.
\end{abstract}

Keywords: Training, Work Motivation, Performance

\section{Introduction}

Basically, the success of a company in achieving the goals is determined by the human element. The potential of human resources is one of essential aspects that holds the most important role in improving the quality of a company. This is confirmed by Gorda (2004: 89) who states that the success of a company can only be achieved with the efforts taken by the human resources and the quality of the human resources it has. A company tends only to demand the high performance of its employees, without considering the factors that influence it. The fundamental factors in supporting performance such as training and work motivation should also be considered.

This is supported by theory proposed by Hasibuan (2011), stating that training and work motivation are needed by companies to develop the capabilities of each employee, in order to accelerate the activities in the company or improve the performance. This is in line with what is stated by Mangkunegara (2006: 51) that all forms of training held by companies must have some components: the training objectives and targets must be clear and measurable, the trainers must be qualified, the training materials must be adjusted to the objectives to be achieved, the training method

Copyright (C) 2019, the Authors. Published by Redwhite Press.

Page | 83 This is an open access article under the CC BY-NC license (http://creativecommons.org/licenses/by-nc/4.0). 
must be in accordance with the ability of the workers who become the participants, and the training participants must meet the specified requirements. In addition to providing training program for the employees, the companies should also give them motivation as a way to encourage the passion to work so that they are willing to work and perform all their abilities and skills to achieve the companies' goals. With high work motivation, the employee performance will increase and the company goals will be achieved. This is supported by Mangkunegara (2000) who argues that work motivation is a condition or energy that moves the employees that are directed or aimed to achieving the goals of the company's organization.

The Regional Drinking Water Company (Perusahaan Daerah Air Minum/PDAM) of Buleleng Regency Branch Seririt is a Regional Government-Owned Enterprise (Badan Usaha Milik Daerah/BUMD) which was established with the purpose of increasing Regional Own-source Revenue (PAD) which is deposited to the regional treasury, and becoming a business entity which provides clean water services to the community. Gradually, PDAM of Buleleng Regency Branch Seririt improves the quality of clean water production in order to satisfy the consumers by utilizing springs that will later affect the company's revenue. The main objective of the establishment is to provide service for the community by fulfilling the need of clean and healthy drinking water for the welfare of the community. The company is located on Jalan Seririt-Gilimanuk, in front of Seririt field and this company has 32 employees.

Based on the background presented above, the problems that can be identified are: (1) Employees at PDAM of Buleleng Regency Branch Seririt have not been able to achieve the target on the Job Implementation Assessment (DP3/Penilaian Pelaksanaan Pekerjaan) set by the company, seen from the 2017 performance achievement data, (2) Employee training at PDAM of Buleleng Regency Branch Seririt is still lack in quantity and quality, which can be seen from the mismatch between the training given and the need of the employees and the fact that there are some employees who have not attended any training program, (3) Lack of employee motivation caused by the low working conditions due to inadequate facilities of work environment such as irregular rooms as the workplace and lack of work desks for the employees, especially for those who are the field officer, as well as less productive relation among the employees, for example the condition that they still bring their personal problems to work (4) Low employee discipline which is reflected in the high frequency of the employees arriving late at work and the employees taking break too long. The purpose of this study was to obtain proven explanations about the effect of: (1) Training and employee work motivation on employee performance at PDAM of Buleleng Regency Branch Seririt, (2) Training on employee work motivation at PDAM of Buleleng Regency Branch Seririt, (3) Training on employee performance at PDAM of Buleleng Regency Branch Seririt, (4) Work motivation on employee performance at PDAM of Buleleng Regency Branch Seririt.

\section{Method}

Based on the characteristics of the problems investigated in this study, the suitable design used for this study was quantitative causal research, a research with the main purpose of proving a causal relationship, so it is clear which variable becomes the cause and which becomes the result (Darsono, 2011). The subjects in this study were employees of PDAM of Buleleng Regency Branch Seririt, while the objects were training, work motivation and performance. This study used a questionnaire method. The training and work motivation were the independent variables and employee performance was the dependent variable. The data analysis used in this study was path analysis, an analysis used to analyze the pattern of indirect relationship. The paradigm or the diagram of research consisted of four sub-structures, namely (1) the effect of training (X1) and motivation (X2) on performance $(\mathrm{Y}),(2)$ the effect of training (X1) on work motivation (X2), (3) the effect of training (X1) on performance $(\mathrm{Y})$, and $(4)$ the effect of work motivation $(\mathrm{X} 2)$ on performance $(\mathrm{Y})$. 


\section{Results and Discussion}

The result and discussion of the study, based on the test of Path Analysis are presented below.

1. There was a positive and significant effect of training and motivation on the performance of employees at PDAM of Buleleng Regency Branch Seririt. With a coefficient of 0.936, the decision rejected the Ho. The contribution of training and motivation to employee performance was $87.7 \%$ while the effect of other factors on employee performance was $12.3 \%$. The other factors which are considered to influence the success of employee performance according to Siagian (2010) and Wibowo (2012) are compensation, leadership, work environment, job satisfaction, work stress, and individual commitment.

2. There was a positif and significant effect of training on performance the performance of employees at PDAM of Buleleng Regency Branch Seririt. With a coefficient of 0.821 , the decision rejected the Ho. The effect of training on employee performance was $82.1 \%$, while the contribution of training on employee performance was $67.4 \%$.

3. There was a positive effect of motivation on employee performance at PDAM of Buleleng Regency Branch Seririt. With a coefficient of 0.435, the decision rejected Ho. The effect of motivation on employee performance was $43.5 \%$ while the contribution of motivation to performance was $18.9 \%$.

4. There was a positive effect of training on motivation of the employees at PDAM Buleleng Regency Branch Seririt. With a coefficient of 0.731 , the decision rejected Ho. The effect of training on motivation was $73.1 \%$ while the contribution of the training to motivation was $53.4 \%$. The effect of other factors on motivation was $46.6 \%$.

\section{Conclusion}

Based on the results and discussion carried out, some conclusions can be drawn as follows. 1)Training and work motivation had a positive effect on employee performance at PDAM Buleleng Regency Branch Seririt, 2)Training had a positive effect on work motivation at PDAM Buleleng Regency Branch Seririt, 3)Training had a positive effect on employee performance at PDAM Buleleng Regency Branch Seririt, 4) Motivation had a positive effect on employee performance at PDAM Buleleng Regency Branch Seririt

\section{References}

Darsono Dan Tjatjuk, Siswandoko. (2011). Manajemen Sumber Daya Manusia Abad 21. Nusantara Consulting. Jakarta

Gorda, I Gusti Ngurah . (2004). Manajemen Sumber Daya Manusia. Edisi Revisi. Denpasar. Astabrata Bali.

Hasibuan. (2011). Manajemen Sumber Daya Manusia, Edisi Revisi, Bumi Aksara. Jakarta.

Mangkunegara. (2000). Manajemen Sumber Daya Manusia Perusahaan. Bandung: PT. Remaja Rosda Karya.

Mangkunegara.(2006). Manajemen Sumber Daya Manusia Perusahaan. Bandung: PT. Remaja Rosda Karya. 